Reprod. Nutr. Dévelop., 1983, 23 (4), 709-715.

\title{
A comparison of ovulatory gonadotropic surge in two rabbit strains : no evidence for a relationship between LH or FSH surge and factors of prolificacy
}

Monique MEUNIER, Françoise HULOT $\left({ }^{*}\right)$, J.-C. POIRIER $\left({ }^{*}\right)$, Suzanne TORRES

Station centrale de Physiologie animale, I.N.R.A. 78350 Jouy-en-Josas, France.

(*) Station d'Amélioration génétique des Animaux, I.N.R.A. B.P. 12, 31320 Castanet-Tolosan, France.

${ }^{* *}$ Station de Physiologie animale, I.N.R.A. Nouzilly, 37380 Monnaie, France.

Summary. Plasma levels of $\mathrm{LH}$ and FSH before and after ovulation were measured in two rabbit strains (New Zealand A 1077 and Californian A 1066) having a different number of ovulations and rate of embryonic loss. Maximal concentrations and total secreted amounts before ovulation were slightly higher in New Zealand, but the difference was not significant.

No relationship between the number of ovulations and the increase in plasma LH or FSH level was found in either strain. In most cases, there was no relationship between gonadotropic surge and early embryonic loss.

\section{Introduction.}

Mating in rabbit causes plasma levels of gonadotropic hormones $\mathrm{LH}$ and FSH to increase (Goodman and Neill, 1976), and ovulation occurring 10 to $12 \mathrm{~h}$ after mating is followed by a second rise in FSH (Osteen and Mills, 1979).

In two rabbit strains selected by Matheron and Rouvier (1977), New Zealand A 1077 and Californian A 1066, the number of ovulations and the rate of early embryonic loss are different (Hulot and Matheron, 1981). These strains seemed to be good models for studying putative relationships between gonadotropic surges, on the one hand, and ovulatory capacity or embryonic development on the other.

\section{Material and methods.}

Nulliparous New Zealand and Californian doe-rabbits, raised under a lighting schedule of $16 \mathrm{~L}: 8 \mathrm{D}$, were mated with males of the same strain at 4.5 months of age. Blood was drawn by intracardiac puncture at various times before and after ovulation, using the technique of Moret (1977). 
$\mathrm{LH}$ and $\mathrm{FSH}$ levels were determined by radioimmunoassay in an homologous specific system. Assay sensitivity of $\mathrm{LH}$ was $130 \mathrm{pg} / 100 \mu \mathrm{l}$ and that of FSH was $25 \mathrm{pg} / 100 \mu \mathrm{l}$ (Blanc et al., to be published). To avoid assay variability, all the samples of the same series were assayed for each hormone during the same incubation. Using a Leitz ASM integrator, we measured the total amount of secreted hormone by the surface of the individual curves, taking the lowest concentration as baseline.

Series 1. - Blood samples were taken from 19 Californian and 26 New Zealand does at regular intervals for $6 \mathrm{~h}$ after mating. The does were killed $96 \pm$ $5 \mathrm{~h}$ after mating. The corpora lutea were counted and the uterine horns perfused to collect the blastocysts which were then counted and measured.

Series 2. - Blood samples were taken from 14 Californian and $14 \mathrm{New}$ Zealand does every hour for the first $16 \mathrm{~h}$ after mating, every $3 \mathrm{~h}$ from 16 to $31 \mathrm{~h}$, then twice a day until day 7 of pregnancy. The blastocysts and their localization in implantation chambers forming in the uterus were counted during exploratory laparotomy at D7 (Wintenberger-Torrès, 1974) after the does had been anesthetized with fentanyl (Hypnorm, U.V.A.).

Statistical analysis. - The F-test (Fisher-Snedecor) was used to compare means and the $\chi^{2}$-test to compare percentages.

\section{Results.}

LH. - In does that had ovulated (100\% in series 1 and $93 \%$ in series 2$)$, $\mathrm{LH}$ concentrations usually begin to rise $30 \mathrm{~min}$ after mating, reaching a maximum after $2 \mathrm{~h}$, returning to basal level at $6 \mathrm{~h}$ after mating and remaining at that level for the first 7 days of pregnancy (figs. 1a, 2a). Individual variations were noted. In several cases, the maximum was reached at $30 \mathrm{~min}, 1 \mathrm{~h}$ or exceptionally at $3 \mathrm{~h}$. Basal levels before mating were higher in series 1 (6.8 \pm $0.2)$ than in series $2(2.6 \pm 0.4)$.

The multiplication factor between basal and maximal levels was 11.8 in series 1 and 52.0 in series 2 . The basal level and the LH pattern were similar in both series in both strains. The levels reached during the ovulatory peak and the total amount secreted were slightly higher in New Zealand. The only significant differences favoring the New Zealand were recorded in series 1 and concerned the total amount of LH secreted and its peak $2 \mathrm{~h}$ after mating.

FSH. - Plasma FSH concentrations began to increase at $30 \mathrm{~min}$, reaching a maximum at 2 to $3 \mathrm{~h}$ after mating, then decreasing up to $8 \mathrm{~h}$ (figs. 1b, 2b); the concentrations increased again at $10 \mathrm{~h}$ after mating, remaining high from 16 to $22 \mathrm{~h}$ and then decreasing gradually to reach the basal level 2 days after mating. Some more or less wide fluctuations were observed up to day 7 of pregnancy (fig. 2b). The basic levels before mating were higher in series $2(1.5 \pm 0.1)$ than in series $1(0.7 \pm 0.07)$. The multiplication factor between the basal level measured before mating and the maximal level reached before ovulation was 9.7 in series 1 and 3.7 in series 2 . 


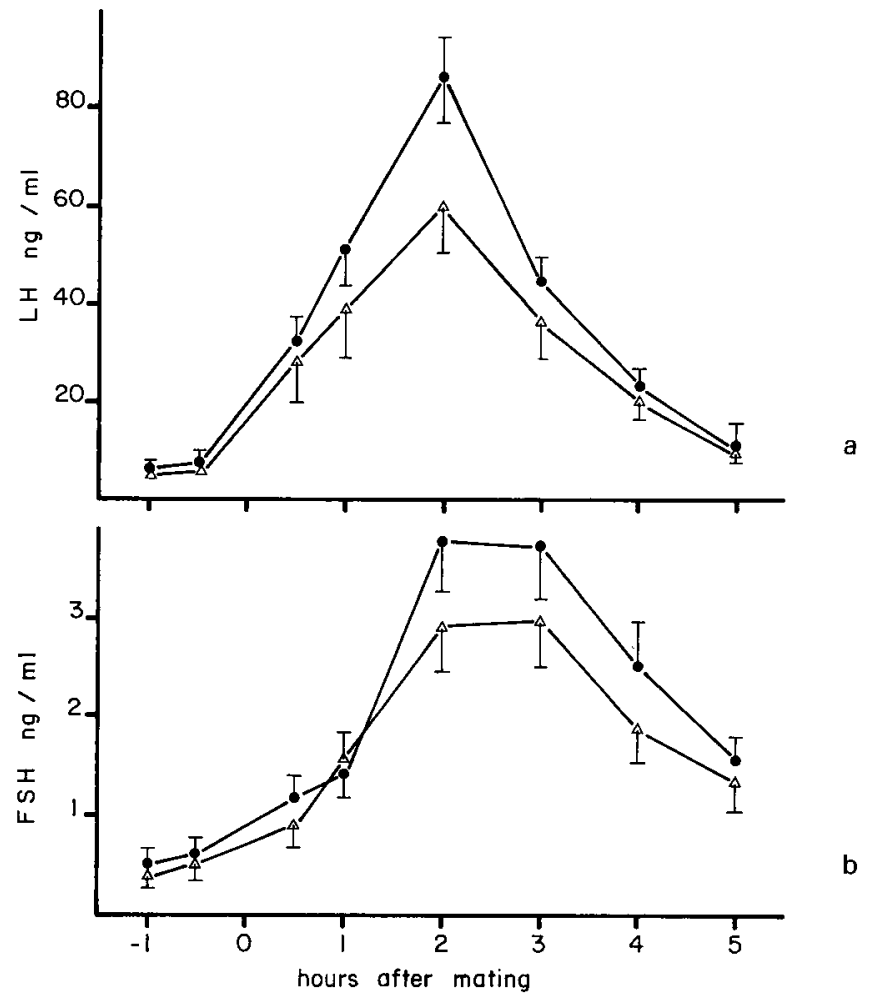

FIG. 1. - Changes in plasma $L H(a)$ and FSH (b) concentrations in Californian $(\Delta-\Delta)$ and New Zealand $(\bullet-\bullet)$ doe-rabbits after mating.

The pattern of FSH concentration and its basal level were similar in both series in both strains. The levels reached during preovulatory and postovulatory peaks and the total secreted amount were slightly higher in New Zealand, on the average, but the difference in series 2 was only significant $4 \mathrm{~h}$ after mating.

Number of ovulations. - The number of ova produced per female was higher in the Californian, although the difference was only significant in series 1 (tables 1, 2). There was no intra or interstrain relationship between the number of ovulations and the increase in plasma $\mathrm{LH}$ or $\mathrm{FSH}$ concentrations during preovulatory surge.

Five of the 71 does ovulating showed no increase in LH and FSH, while 6 showed no increase in FSH (table 3). Except for one Californian which had only 6 corpora lutea, the number of ovulations in these females was not different from that of does showing peaks of $\mathrm{LH}$ and $\mathrm{FSH}$.

Embryonic loss. - The percentage of does losing their litter before 4 (series 1) or 7 (series 2) days was the same in both strains (tables 1,2). In the other 


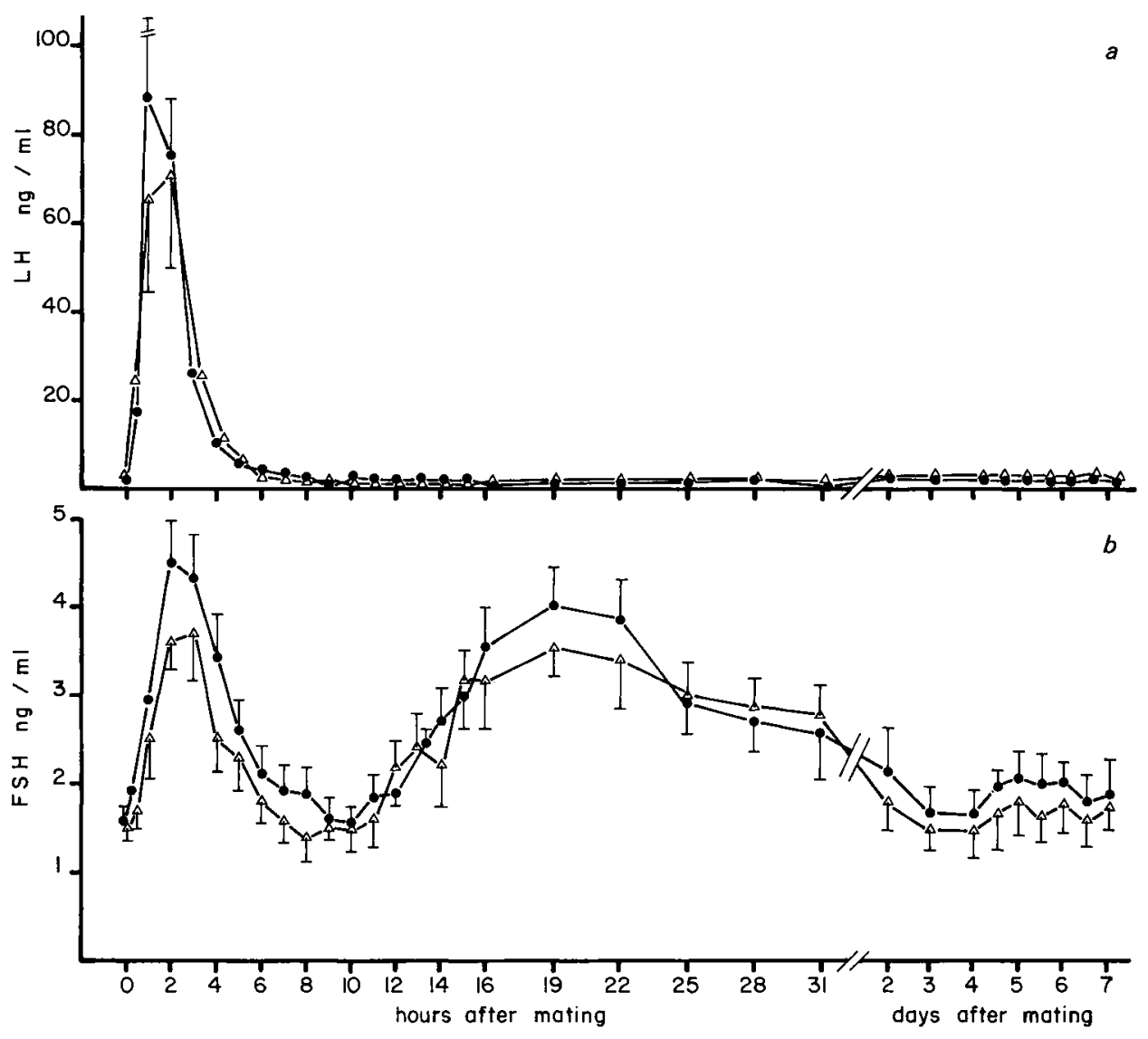

FIG. 2. - Changes in plasma $L H$ (a) and FSH (b) concentrations in Californian $(\Delta-\Delta)$ and New Zealand (•-•) doe-rabbits after mating.

TABLE 1

Number of ovulations and embryonic loss at $96 \mathrm{~h}$ after mating.

\begin{tabular}{ccccccc}
\hline \multirow{2}{*}{ Strain } & Number of & $\begin{array}{c}\text { Does with } \\
\text { ovulations }\end{array}$ & \multicolumn{4}{c}{ Partial or no embryonic loss } \\
\cline { 5 - 7 } & onic loss & $\begin{array}{c}\text { Number of } \\
\text { ovulations }\end{array}$ & $\begin{array}{c}\text { Number of } \\
\text { blastocysts }\end{array}$ & Loss & $\begin{array}{c}\text { Blastocyst dia- } \\
\text { meter (in } \mu \mathrm{m} \text { ) }\end{array}$ \\
\hline Californian & $\begin{array}{c}12.0 \pm 0.6 \\
\mathrm{n}=19\end{array}$ & $\begin{array}{c}16 \% \\
\mathrm{n}=3\end{array}$ & $\begin{array}{c}12.3 \pm 0.7 \\
\mathrm{n}=16\end{array}$ & $\begin{array}{c}10.1 \pm 0.6 \\
\mathrm{n}=16\end{array}$ & $18 \%$ & $\begin{array}{c}366 \pm 9 \\
\mathrm{n}=162\end{array}$ \\
\hline New Zealand & $\begin{array}{c}10.0 \pm 0.4 \\
\mathrm{n}=26^{* *}\end{array}$ & $\begin{array}{c}12 \% \\
\mathrm{n}=3\end{array}$ & $\begin{array}{c}10.0 \pm 0.5 \\
\mathrm{n}=23^{* *}\end{array}$ & $\begin{array}{c}9.0 \pm 0.5 \\
\mathrm{n}=23\end{array}$ & $\begin{array}{c}10 \% \\
*\end{array}$ & $\begin{array}{c}437 \pm 9 \\
\mathrm{n}=207^{* * *}\end{array}$ \\
\hline
\end{tabular}

$\mathrm{n}=$ number of does; ${ }^{*} \mathrm{P}<0.05 ;{ }^{*} \mathrm{P}<0.01 ;{ }^{* * *} \mathrm{P}<0.005$. 
TABLE 2

Number of ovulations and embryonic loss at 7 days of pregnancy.

\begin{tabular}{|c|c|c|c|c|c|c|}
\hline \multirow{2}{*}{ Strain } & \multirow{2}{*}{$\begin{array}{l}\text { Number of } \\
\text { ovulations }\end{array}$} & \multirow{2}{*}{$\begin{array}{l}\text { Does with } \\
\text { total embry- } \\
\text { onic loss }\end{array}$} & \multicolumn{4}{|c|}{ Partial or no embryonic loss } \\
\hline & & & $\begin{array}{l}\text { Number of } \\
\text { ovulations }\end{array}$ & $\begin{array}{l}\text { Number of } \\
\text { blastocysts }\end{array}$ & $\begin{array}{c}\text { Number of } \\
\text { sites }\end{array}$ & Loss \\
\hline Californian & $\begin{array}{c}11.5 \pm 0.7 \\
n=14\end{array}$ & $\begin{array}{c}7 \% \\
n=1\end{array}$ & $\begin{array}{c}12.2 \pm 0.7 \\
\mathrm{n}=10\end{array}$ & $\begin{array}{c}9.7 \pm 1.0 \\
n=10\end{array}$ & $\begin{array}{c}8.7 \pm 1.3 \\
n=10\end{array}$ & $30 \%$ \\
\hline New Zealand & $\begin{array}{c}10.3 \pm 0.3 \\
n=12\end{array}$ & $\begin{array}{c}8 \% \\
n=1\end{array}$ & $\begin{array}{c}10.4 \pm 0.4 \\
n=8\end{array}$ & $\begin{aligned} 9.0 & \pm 0.4 \\
n & =8\end{aligned}$ & $\begin{array}{c}8.8 \pm 0.5 \\
n=8\end{array}$ & $16 \%$ \\
\hline
\end{tabular}

$n=$ number of does : ${ }^{*} P<0.05$.

TABLE 3

Embryonic loss in does showing no simultaneous preovulatory peaks of LH and FSH.

\begin{tabular}{cccc}
\hline \multirow{2}{*}{ Number of does } & \multicolumn{2}{c}{ Increase } & \\
\cline { 2 - 3 } & in LH & in FSH & $\begin{array}{c}\text { Embryonic } \\
\text { loss (\%) }\end{array}$ \\
\hline 5 & - & - & 100 \\
\hline 1 & + & - & 100 \\
1 & + & - & 80 \\
1 & + & - & 50 \\
\hline 3 & + & - & $0-20$ \\
\hline
\end{tabular}

does, embryonic loss at 4 or 7 days was higher in Californian than in New Zealand. Blastocyst diameter at $96 \mathrm{~h}$ after mating was significantly smaller in the Californian (tables 1, 2).

Nine (15\%) of the 60 does showing a rise in LH and FSH before ovulation had an embryonic loss of 50 to $100 \%$ at D4 or D7. Eight (73\%) of the 11 does showing no peaks of $\mathrm{LH}$ and $\mathrm{FSH}$, or of FSH only, had an embryonic loss of more than $50 \%$ (table 3 ). The difference between these two groups was significant $(p<0.005)$.

\section{Discussion.}

Of the two rabbit strains we used, the Californian had the higher number of ovulations and higher embryonic loss (Hulot and Matheron, 1981). On the average, however, basal level and plasma concentrations of LH and FSH before and after ovulation were comparable, although the LH peaks were slightly higher (but not significantly so) in the strain that ovulated less.

We found no relationship between the elevation of LH before ovulation and the number of ovulations. In the ewe, the preovulatory LH peak is identical, whatever the ovulation rate (Thimonier and Pelletier, 1971 ; Land et al., 1973 ; Quircke et al., 1979). 
According to Bindon et al. (1979), basal FSH levels are higher before estrus in Ile-de-France ewes (which have a low ovulation rate) than in Romanoff ewes. Such a difference was not found between the two rabbit strains we studied. However, our results on the preovulatory FSH peak agree with those of Bindon et al. (1979) and Cahill et al. (1981), i.e. hormone levels were slightly higher in the strain that ovulated less. The postovulatory peak in ewe (Cahill et al., 1981) was significantly higher $(p<0.05)$ in Romanoff which is the more prolific strain ; our results in rabbit would not agree with this.

Cahill et al. (1981) studying ewe, suggested that the ovulation rate in a given cycle depends on the postovulatory FSH level in the previous cycle, determining the number of antral follicles in the ovary. In rabbit it is difficult to imagine the role of the postovulatory peak on an ovulation occurring after mating in the more or less distant future.

The difference in the number of ovulations in the two strains of rabbit we examined would be due to the number of preovulatory follicles (higher in the Californian) (Hulot and Mariana, 1982) and would not depend on successive hormonal surges following mating.

Embryonic loss is lower in New Zealand than in Californian, as shown by the number of implantations. We did notice that when embryonic loss was higher than $50 \%$, it was almost always associated with the absence of preovulatory peak or with a very short surge of $\mathrm{FSH}$. The postovulatory surge of $\mathrm{FSH}$ would induce maturation of a new wave of follicles. The secretion of estrogen by these follicles would maintain the hormonal balance needed for the progression of the blastocysts through the oviduct and for the release, by oviduct epithelial cells, of the mucopolysaccharides surrounding the rabbit blastocyst as it moves through the Fallopian tubes (Greenwald, 1961). However, since the work of Greenwald (1962), we know that the normal development of the blastocyst is related to the thickness of the mucin layer.

A modification in the surge of FSH could therefore change estrogen balance and thus affect the transit of the blastocysts and the thickness of the mucin layer, impairing the normal development of the embryos.

Reçu en juin 1982.

Accepté en février 1983.

Acknowledgements. - We wish to thank M. Cattiau, Régine Monnerie, B. Moret and Claude Rebours who did the blood sampling and Dr. A. Parlow who gave us the RIA kits.

Résumé. Comparaison des décharges gonadotropes chez deux souches de lapine, en relation avec le taux d'ovulation et la mortalité embryonnaire.

Les niveaux plasmatiques de LH et de FSH ont été mesurés avant et après l'ovulation dans deux souches de lapines qui diffèrent par le nombre d'ovulations et la mortalité embryonnaire. Les concentrations maximales et les quantités totales sécrétées avant l'ovulation sont légèrement supérieures dans la souche Néo-Zélandaise, mais la différence n'est pas significative. 
Dans les deux souches, aucune relation n'a été trouvée entre le nombre d'ovulations et l'augmentation des niveaux plasmatiques de $\mathrm{LH}$ ou de $\mathrm{FSH}$. Dans la majorité des cas, il n'est pas non plus possible d'établir de relation entre l'intensité des décharges gonadotropes et la mortalité embryonnaire précoce.

\section{Références}

BINDON B. M., BLANC M. R., PELLETIER J., TEROUI M., THIMONIER J., 1979. Periovulatory gonadotrophin and ovarian steroid patterns in sheep of breeds with differing fecundity. $J$. Reprod. Fert., 55, 15-25.

CAHILL L. P., SAUMANDE J., RAVAULT J. P., BLANC M., THIMONIER J., MARIANA J. C., MAULĖON P., 1981. Hormonal and follicular relationships in ewes of high and low ovulation rates. J. Reprod. Fert., 62, 141-150.

GOODMAN A. L., NEILL J. D., 1976. Ovarian regulation of post-coital gonadotropin release in the rabbit. Reexamination of a functional role for $20 \alpha$-dihydroprogesterone. Endocrinology, 99, 852-860.

GREENWALD G. S., 1961. A study of the transport of ova through the rabbit oviduct. Fert. Steril., $12,80-95$.

GREENWALD G. S., 1962. The role of the mucin layer in development of the rabbit blastocyst. Anat. Rec., 142, 407-415.

HULOT F., MATHERON G., 1981. Effets du génotype, de l'âge et de la saison sur les composantes de la reproduction chez la lapine. Ann. Génét. Sél. anim., 13, 131-150.

HULOT F., MARIANA J. C., 1982. Comparaison de la population des follicules préovulaires entre deux souches de lapins. Effet de la parité et de la saison. $3^{e}$ Journ. Recher. cunic., INRAITAVI, ITAVI ed. Paris, Communic. $\mathrm{n}^{\circ} 13$.

LAND R. B., PELLETIER J., THIMONIER J., MAULÉON P., 1973. A quantitative study of genetic differences in the incidence of oestrus, ovulation and plasma luteinizing hormone concentration in the sheep. J. Endocr., 58, 305-317.

MATHERON G., ROUVIER R., 1977. Optimisation du progrès génétique sur la prolificité chez le lapin. Ann. Génét. Sél. anim., 9, 393-405.

MORET B., 1977. Présentation d'un système simple de contention pour ponction cardiaque sur le lapin. Cuniculture, 4, 201-202.

OSTEEN K. G., MILLS T. M., 1979. Serum LH and FSH levels in the pregnant rabbit (40703). Proc. Soc. exp. Biol. Med., 162, 454-457.

QUIRKE J. F., HANRAHAN J. P., GOSLING J. P., 1979. Plasma progesterone levels throughout the oestrus cycle and release of $\mathrm{LH}$ at oestrus in sheep with different ovulation rates. $J$. Reprod. Fert., 55, 37-44.

THIMONIER J., PELLETIER J., 1971. Différence génétique dans la décharge ovulante (LH) chez les brebis de race lle-de-France: relations avec le nombre d'ovulations. Ann. Biol. anim. Bioch. Biophys., 11, 559-567.

WINTENBERGER-TORRÉS S., 1974. Relation entre la taille des blastocystes de lapine à l'ímplantation et la survie embryonnaire. Ann. Biol. anim. Bioch. Biophys., 14, 41-52. 